\title{
Tutor Capacity Building Efficacy in Preservice Teacher Preparation for Inclusive Schools: An Exploratory Study
}

\author{
Lawrence Eron \\ Department of Special Needs Studies, Kyambogo University, Kampala, Uganda \\ Email: elawrence@kyu.ac.ug
}

How to cite this paper: Eron, L. (2021). Tutor Capacity Building Efficacy in Preservice Teacher Preparation for Inclusive Schools: An Exploratory Study. Open Journal of Social Sciences, 9, 398-413. https://doi.org/10.4236/jss.2021.97029

Received: June 12, 2021

Accepted: July 23, 2021

Published: July 26, 2021

Copyright (c) 2021 by author(s) and Scientific Research Publishing Inc. This work is licensed under the Creative Commons Attribution International License (CC BY 4.0).

http://creativecommons.org/licenses/by/4.0/

\begin{abstract}
In-service tutor development on inclusive education provides an opportunity for preparing student teachers to educating all children. This study aimed to investigate the efficacy of teacher educators' capacity and commitment for quality training of student teachers towards inclusive education in Uganda. The study adopted a qualitative approach. Participants included tutors $(\mathrm{N}=$ $8)$, students with disabilities $(\mathrm{N}=8)$ and students without disabilities $(\mathrm{N}=$ 56). Individual interviews were conducted with tutors and students with disabilities while focus group discussions were held with students without disabilities. Data was analyzed using themes generated from transcripts. Results of this study indicate increased support to a number of students with disabilities admitted in primary teacher colleges. It however noted the need for skills in functional assessment, braille and sign language, modifying methods and providing resources to accommodate individual disability. The study recommended increased mentorship, improved skills in functional assessment and continuous professional development in inclusive education. These findings identify modifications in teacher education intended to promote inclusive learning for children with disabilities and other special needs.
\end{abstract}

\section{Keywords}

Inclusive Education, Special Needs Education, Teacher Development, In-Service

\section{Introduction}

In recent years, Uganda has embraced the Sustainable Development Goal \# 4 to "ensure inclusive and equitable quality education and promote lifelong learning 
opportunities for all by 2030" (UN, 2015). Like many countries of the world, there are challenges in initial teacher development towards inclusive education. Tutor development on inclusive education provides an opportunity for preparing student teachers in educating all children. To reduce significant stress in primary education system, training in special needs education for initial teacher trainees has been adopted. Special needs education is made a component of the Professional Educational Studies (PES) studied by all teacher trainees in the Primary Teachers' Colleges (PTCs). However, literature indicated that such components provide very little introductory information (Tungaraza, 2014). According to Ahmadi \& Keshavarzi, (2013), teacher trainees need to have teacher educators with the required knowledge, skills and practice to attain the required competence in special needs education. Teacher development approach within a teacher education programme helps to provide a "multi-dimensional awareness" and "the ability to apply this awareness to their actual contexts of teaching" (Mann, 2005).

Education is a universal right, provided for within the United Nations Convention on the Rights of Persons with Disabilities (CRPD). Uganda ratified its Optional Protocol in September 2008 and was a signatory to Sustainable Development Goals (SDGs) as well as the Education for All (EFA) global movement. In Uganda, the right to education is enshrined in the following legal documents; the Constitution of the Republic of Uganda (1995), Education Act 2008, Local Government Act 1997 as amended and other Acts of Parliament providing for equality and non-discrimination.

The effectiveness of education and training in social development arises from its ability to solve all existing problems of the society and removing all obstacles in society's economic and social progress and development (Ahmadi \& Keshavarzi, 2013). The need for inclusive education is considered the best strategy to ensure that all children access-curricula and teaching, schools, and appropriate technology, quality education-education that appreciates individual differences, learning styles, academic levels, etc., and values-all students equally, promoting participation, eliminating discrimination, etc. (Booth 2009). Inclusive education claims the need for equal learning opportunities to be provided in mainstream schools that are prepared to accommodate all learners regardless of their individual characteristics (Symeonidou, 2017). Commitment to inclusive education in Uganda is demonstrated by the legal and non-legal frameworks on education and the establishment of educational infrastructure aimed at mainstreaming disability (Emong \& Eron 2016). These commitments have enabled increasing numbers of children with disabilities and other special needs to be enrolled in inclusive schools, however, their attendance, completion and transition rates and levels of achievement tend to be very low (Moyi, 2012).

Inclusive education requires teacher educators to accept the responsibility for preparing students teachers who can support all children to learn and feel a sense of belonging. Three key aspects that demonstrate a well-prepared teacher 
is his or her readiness to include all learners through the "heart" indicating ethical and moral dimensions, "head" reflecting knowledge and skills to teach students with diverse characteristics and backgrounds, and "hands" the application of inclusive pedagogy in real settings (Sharma \& Pace, 2019). Thus, initial teacher training plays a central role in shaping the minds of pre-service teachers. Preparing teachers to adopt an inclusive approach to education involves not only identifying the components of effective approaches for teacher education, but the nature of the education systems and schools in that country (Symeonidou, 2017). This argument is necessary to explain the intention of building the capacity of teacher educators to encourage pre-service teachers to develop professionally. As teacher educators ponder upon the extent to which their own practice is framed within an inclusive paradigm and whether their convictions, the choice of content, and whether their setting creates the ideal backdrop, future teachers are expected to replicate in their own schools and classrooms for inclusion to take place (Sharma \& Pace, 2019).

Studies have been conducted in Uganda about teacher recruitment, deployment, absenteeism (Cilliersa et al., 2014), teacher attrition, motivation (Tumwebaze \& MacLachlan, 2012) and opportunities for career development, job satisfaction and the existing context for social dialogue (UNESCO, 2013b). Various studies concluded that many factors affect the quality of education including and not limited to lack of capacity and commitment of teachers, inadequate education infrastructure, prevalent negative social attitudes, overcrowded classrooms, and shortage of necessary teaching and learning resources in schools (Arbeiter \& Hartley, 2002; Najingo, 2009; Nyende, 2012). Teaching in inclusive schools is complex (Sharma \& Pace, 2019). Most of the developed countries spend a great deal of their gross national income in various ways on the education and training of human resources in order to survive, develop and progress (Ahmadi \& Keshavarzi, 2013). This survival, development and progress are demonstrated through the methods, skills and attitudes that teachers demonstrate in their self-development. According to Mann (2005) self-development is a measure that takes into consideration to a large extent self-direction. Challenge in the quality of education is compounded by the gap in the current pupil enrolment projection to teacher presence and performance. There is nearly half of the population below the age of 5 years (Daumerie \& Madsen, 2010) and the population structure is expected to remain youthful for the next fifteen years, as shown in Table 1.

While these projections are indicative figures for planning, the figures lack segregated details for children with disabilities and other special needs. The lack of segregation implies that the individual needs of learners with disabilities and other special needs have not been identified and cannot be met, thus calling for strategic planning for them. In most cases the right to education for students with disabilities in Uganda is still suffering from discrimination (Emong \& Eron, 2016). 
Table 1. Evolution of the school aged population, 2010-25.

\begin{tabular}{cccccc}
\hline & 2010 & 2015 & 2020 & 2025 & $\begin{array}{c}2025 / 2010 \\
\text { Ratio }\end{array}$ \\
\hline Total Population & $\mathbf{3 1 , 7 8 4 , 3 2 0}$ & $\mathbf{3 7 , 9 0 6 , 7 0 0}$ & $\mathbf{4 5 , 0 5 6 , 7 1 7}$ & $\mathbf{5 3 , 6 4 5 , 4 4 6}$ & $\mathbf{1 . 7}$ \\
3 - 5 years & $3,651,770$ & $4,441,890$ & $5,092,124$ & $6,013,077$ & 1.6 \\
6 - 12 years & $6,538,950$ & $8,317,330$ & $10,588,112$ & $13,473,293$ & 2.1 \\
13 - 16 years & $2,966,970$ & $3,539,910$ & $4,396,614$ & $5,352,059$ & 1.8 \\
17 - 18 years & $1,368,310$ & $1,526,320$ & $1,611,902$ & $1,749,507$ & 1.3 \\
Total 6 - 18 Years & $10,874,230$ & $13,383,560$ & $16,596,627$ & $20,574,859$ & 1.9 \\
Total 6 - 18 Years (\%) & $34.2 \%$ & $35.3 \%$ & $36.8 \%$ & $38.4 \%$ & \\
\hline
\end{tabular}

Source: Uganda-MoES (TIISA-2013).

\section{Inclusive education in context}

There are many competing definitions of inclusive education. The general consensus is the fundamental right that all children should be given access to quality education to ensure they reach their full potential as individuals (Sulochini \& Slee, 2019). Inclusive education is backed by a number of evidence-based practices identified by Tschantz \& Vail (2000) as peer coaching, Mather and Muchatuta (2011) as variety of teaching and learning methods, Buysse \& Peisner-Feinberg (2010) as multi-tiered systems of support and Stockall, Dennis, \& Miller (2012) as universal design for learning. In implementing inclusive education, the principles of inclusion and equity are considered key in ensuring access to education as well as having quality learning spaces and pedagogies that enable students to thrive, to understand their realities, and to work for a more just society". In spite of these well-defined principles, there is still lack of clarity on how to move policy and practice towards inclusive education forward.

This article presents recent developments in the Primary Teachers Colleges towards inclusive education and the broader discussion about the role of teacher educators in preparing student teachers for educating all children. It explores the capacity and commitment for quality training of student teachers and identifies modifications intended to promoting inclusive learning and training of children with disabilities and other special needs. Primary teacher education in Uganda attracts qualified candidates from the ordinary level of education. Having no prior training in teacher education, these candidates are introduced to theoretical and practical knowledge and skills necessary to become a professional and certified teacher. The PTC curriculum consists of subject matter domain: mathematics education, language education, science education, social studies and cultural education subjects; professional studies: foundation of education, special needs education and instructional materials and practicum, school practice and child study (Aguti, 2003). Quality assurance is a designated responsibility of Kyambogo University. The Ministry of Education and Sports provide policy guidelines, funds and is the overall supervisor. 


\section{Methodology}

This was a descriptive qualitative study designed to identify the scope, implementation and impact of the special needs education component in the Primary Teacher Curriculum. The emphasis was to gain insights (Denzin \& Lincoln, 2000; Patton, 2002) and document voices and subjective human experiences (Silverman, 2010) of the tutors on how the special needs education component is being taught in PTCs and the challenges that should inform appropriate planning.

A mixture of purposive and simple random sampling was adopted to identify the colleges and participants. Eight Primary Teachers' Colleges (offering both in-service and preservice training) and four Pre-service Colleges were purposively selected. These Colleges had students with disabilities admitted or where the special needs education distance education programme being offered. A sample of a tutor $(\mathrm{N}=1)$ from each college who is teaching the special needs component was done. A simple random sampling of students with disabilities (N $=1)$ and student without disability $(\mathrm{N}=7)$ was thereafter made in each college. Details about participant characteristics are presented in Table 2.

A combination of in-depth individual interview and focus group discussion was used for data collection. Individual interviews were administered to the tutors and students with disabilities. Focus group discussions were held with students without disabilities in the colleges. The interview and focus group discussion guides were designed based on predetermined themes focused on issues relating of enrolment, dropout and progression of students with disabilities, functional assessment, adaptation of curriculum materials, alternative communication skills, environmental adaptation and professional training gaps. The instruments were developed and reviewed by the team who collected the data.

The interviews started with students with disabilities from each college, followed by focus group discussion and later tutors were interviewed. Interviews lasted a duration between 45 and 70 minutes and were conducted in an open space under the tree within the college compound considered to private enough. The focus group discussion took between 60 to 90 minutes and carried out in the same environment of interviews. As the sampling was done on the same day of the interview, all participants were engaged. This being an institutional environment with official language being English, all interviews were conducted in English and audio recorded.

Data obtained from each of the instruments were analysed based on the themes. Closed ended and open-ended questions were clustered, transcribed

Table 2. Participants' characteristics.

\begin{tabular}{cccc}
\hline Participants & Number per College & Total Number & Method \\
\hline Tutors & 1 & 8 & Individual Interview \\
Students with disabilities & 1 & 8 & Individual Interview \\
Students without disabilities & 7 & 56 & Focus Group Discussion
\end{tabular}


into text, grouped based on the predetermined themes, coded and analysed manually and grouped basing on the key issues it represented. For purposes of expressing issues on inclusive education strongly, voices of respondents are reported. Ethical commitments were adhered to in the process of the study. These included informed consent, confidentiality and anonymity. Participants were requested to consent by signing a form before the interview began. They were also informed that they had the right to withdraw from participation at any time without explanation. None of the participants withdrew from the study. To ensure confidentiality and anonymity, pseudonyms have been used throughout to present verbatim statements.

\section{Findings}

The findings from this study shed light on questions of enrolment, functional assessment, and adaptation of curriculum materials. It explores development made and challenges relating to alternative communication skills, modifications made in the school for reasonable accommodation as well as professional training gaps.

Characteristics of respondents

From the findings of the study a total of 72 respondents were involved drawing largely from among the tutors, students with disabilities and those without disabilities. The study engaged one tutor responsible for teaching special needs education and sampled only one student with disabilities from each college. Seven students without disabilities were randomly sampled and involved through a focus group discussion. Students without disabilities were drawn from among new and continuing students.

\section{Rate of enrolment, drop-out and progression of students in the colleges}

Findings on rate of enrolment, drop-out and progression of students with disabilities and other special educational needs in Primary Teachers' Colleges (PTCs) varied. Some colleges admitted students with disabilities and catered for their special needs while others rejected their admission on noticing that they have a disability or special needs. Results indicated that some applicants with unrecognized (mild to moderate) disabilities were admitted and stayed on the course until they completed their studies. Physical disability was considered to be a moderate impairment. In one college in Northern Uganda students with physical disabilities $(\mathrm{N}=2)$ and deaf $(\mathrm{N}=1)$ progressed well up to completion of their studies. Other colleges reported providing equal access to all applicants as long as they meet the minimum entry requirements or affirmative action provision stipulated by the Ministry of Education and Sports. But, since they did not have students who needed assessment, they could not assess the needs of students and modify for the facilities. As observed by a tutor "our college is inclusive, we admit any student who qualities or meets affirmative requirements for disability, unfortunately, this year we don't have any" (Tutor 6).

However, some PTCs denied admission opportunities for some categories of applicants who had disabilities and other special needs. Results indicated that 
three applicants with special needs: visual impairment (blind $\mathrm{N}=1$ and Low Vision $\mathrm{N}=1$ ), and deaf $\mathrm{N}=1$ applied for admission to one PTC in Western Uganda but were denied admission chances on grounds that the college had no tutors to cater for their learning needs. In another college in central Uganda, a female Deaf student $(\mathrm{N}=1)$ was enrolled in in-service program but dropped out of the college for unknown reasons.

Findings indicated that the rate of enrolment of students with disabilities was very low in most colleges in comparison to the enrolment of ordinary students. In a focus group discussion with students without disabilities, one group observed "our colleagues especially the deaf and the blind are denied admission because the college does not have facilities and tutors to help them" (FGD II).

Considering the broader definition of special needs, results indicated that girls who got pregnant during their studies were conditioned to drop out of the colleges. However other colleges helped such girls to complete their course after they have delivered.

\section{Functional Assessment}

Most respondents during interviews and focus groups reported that all colleges had a few students with disabilities and other special educational needs. They noted that there is no assessment carried out to find out if someone has a disability or special needs. One student with special needs said "for us we are not assessed when we report to college. The information we give is what we were told when still at the primary school" (SN IV).

The reported special needs in the colleges included motor/physical and sensory (visual and hearing) impairments. The impairments of these students were known at admission. There were reports of functional assessment carried out by development partners during the time when the students were still in high school. But there was no evidence of reports on functional assessment of the current or past students. The lack of functional assessments was linked to the lack of tutors with knowledge on how to carry out the assessment. A tutor observed: "Functional assessment to identify special learning needs of the students were not done since there were no tutors with qualifications in SNE \& IE in most colleges. Those with qualifications in Special Needs Education had assessment skills of special learning needs in the students but lacked tools" (Tutor I). From the perspective of students; "Learners with special learning needs that would be visibly seen, example physical impairment and visual impairment, were identified through observation of their unique characters like coming closer to the chalk board in an attempt to read teachers' notes" (FGD III).

In West Nile region, it was reported that information on functional assessment of learners with disabilities and other special needs when still in the primary schools was being used. The assessment was done through the help of development partners; Uganda Society for Disabled Children (USDC), medical personnel and Special Needs Education/Educational Assessment and Resource Services (SNE/EARS). There were no copies of these reports as they were kept by the development partners and not given to the schools or parents of those learn- 
ers. "Our students are assessed while still in the primary school, unfortunately, their results are not given to us when they join the college. We are told the organization that carried out the assessment went with them" (Tutor 8).

Findings from colleges in Western Uganda indicated that functional assessment was done by specialist teachers at some primary schools. These reports were kept at the school and no documented reports were available at the Primary Teachers' Colleges. Other assessments involved physiotherapists, ENT and ophthalmologists to inform on mobility, hearing and visual challenges that required interventions. Copies of these reports are carried along by the students when they report to the college.

\section{Adaptation and use of curriculum materials}

Adaptation and use of curriculum materials to meet the learning needs of the learners were reported in some colleges. Teacher trainers reported that they brailled some of the curriculum materials for students who are blind. They also indicated that colleges provide sign language interpreters and audiovisual materials for Deaf student to facilitate their learning. In another college finding indicated that some students with low vision and hearing impairment were placed in the front seats to help them follow instructions.

Results on adaptation and use of curriculum materials for students reveal that curriculum materials were not adapted in most colleges to meet the learning needs of students with disabilities and other special educational needs (SEN). As observed by one student with visual impairment "charts and other illustrations in classes have no embossed features. These could not benefit us students who are blind" (SN 4). Teacher trainers reported that they explain the charts and illustrations verbally to the students.

Results indicated that only one of the colleges visited provided extra times. Extra time gave opportunity to guide students with disabilities and other special educational needs from designated "resource rooms". It reported that the guidance was in form of overlearning what had been learnt from mainstream classes. This included dictating of notes for the blind learners to braille and additional explanation in sign language. Students were also given extra time during examinations and tests.

Developing alternative communication skills

Findings on training students to develop alternative communication skills reveal that sign language and Braille were not being taught in all colleges due to lack of tutors who had expertise skills and knowledge in the areas. Similarly, sign language and braille were not examined during the Teacher Education National Examination. Learners with low vision in some colleges were encouraged to use their residual vision to read ordinary prints.

Findings indicated that some colleges had tutors who are qualification in Special Needs Education. The tutors reported having limited time to train and practice skills needed in sign language and braille with students on the time table. As observed by one tutor, "We are allocated limited time to teach special needs education. You cannot have time to practice sign language and braille to the 
benefit of the students" (Tutor VII). In one college, the tutor of Special Needs Education had gone for further training so there were no other tutors who could train student teachers in the alternative communication skills which they were handling.

Results on how students and tutors interact indicated that there was free and easy communication between students and tutors. Data indicated that students communicated with tutors through assemblies and through their personal tutors and letters. Findings also indicated that student teachers with disabilities and other special needs education would freely communicate using speech and written information with their tutors. Teacher educators in some colleges reported experiencing challenges communicating with their students who are Deaf since they did not know sign language.

\section{Modification made in the school environment}

Findings on modification made in the school environment in relation to the needs of students with disabilities and other special educational needs at the Colleges were positive. All new buildings (classrooms, libraries and laboratories) at the colleges were fitted with ramps, accessible doors and had wide windows for adequate and sufficient lighting. Old buildings in majority of colleges did not have adaptations. Others had very high steps which are not easily accessible by wheel-chair users. There were pathways that led to different buildings at the colleges. Toilets were adapted/modified to cater for student teachers and other persons with physical impairments. Handles were fitted in them to ease squatting. Its doors were wider enough for wheel chairs to easily reach in and get out of it. On qualities of buildings, classrooms, laboratories and teaching spaces in relation to accessibility, comfort, safety, cleanliness and security/protection, students with disabilities agreed that: "All college buildings are clean, safe and secure. Some buildings cannot easily be accessible by physically impaired students due to high steps and poorly installed ramps. Most buildings, laboratories, classrooms and teaching spaces are easily accessible" (FGD II).

Findings on quality of display around the college that considers diversity of students indicate that messages were displayed around the colleges that targeted ordinary students specifically. Very little displays were about disabilities and other special educational needs. One college had a display saying "Disability is not inability". As noted a student with disability: "All sign posts planted at various points within the colleges are not modified to accommodate students with visual impairment" (SN VII).

On classroom organization taking into consideration students with disabilities and other special educational needs, findings reveal that classrooms in most colleges were well organized to cater for the needs of all students including students with disabilities and other special educational needs. A student with disability noted "Majority of the classroom have good walkways, good sitting arrangements, and comfortable writing spaces to accommodate my physical disability" (SN IV). 
Findings on availability and adequacy of relevant instructional materials, compensatory and assistive devices for students with disabilities and other special educational needs show that there were no specialized materials for students with disabilities and other special educational needs in all colleges. As observed by a student with disability "we are not given any ccompensatory appliances and assistive devices. What we are using is what we came with, otherwise we have to persevere the learning like that" (SN III).

On availability of proper, dignified and hygienic sanitation and facilities that take account of disabilities and special needs of girls at colleges' findings indicate that enough sanitation facilities for both male and female students were available in all colleges. As noted in an FGD: "We have toilets designed with inset bar-handles, wide doors and ramps to ease access to student teachers and other persons with disabilities and other special needs" (FGD III).

Findings on availability of recreational facilities, clubs and physical education activities for students that include students with disabilities and other special educational needs at colleges reveal that provisions were made in different college clubs and recreational facilities. As observed by one tutor "basketball pitch, volleyball pitch, and football field is used by all student teachers including students with disabilities and other special educational needs in the colleges. However, there is no special design specifically for students with disabilities" (Tutor I).

Findings on availability of adequate space for organization of learning activities at colleges reveal that classrooms, laboratories, and assembly halls in all colleges had adequate space that could enhance organization and conduct of learning activities (group work and demonstrations) for all students including student teachers with disabilities and other special educational needs. Data indicated that student teachers with disabilities and other special educational needs were involved in college leadership and administration in a few colleges. As observed by a college tutor: "we involved a student with physical impairment as head-girl. I also know that it is a requirement for students with disabilities (PwDs) to be involved in college management in all colleges" (Tutor V). Some College administrators regretted that it was an oversight which would be considered in their subsequent elections. Data indicated that some colleges claimed not to have student teachers with disabilities and other special educational needs, so college administration and leadership did not involve students with disabilities. A tutor observed "we do not have students with disabilities that is why they are not involved in the college administration. We have no problem involving them" ( $\mathrm{Tu}-$ tor II).

\section{Professional and training gaps}

Professional and training gaps identified for the implementation of special needs and inclusive education practices in Primary Teachers Colleges included lack of alternative communication skills in Ugandan Sign Language (USL), Braille as well as lacked skills on identification and assessment of disabilities and other special educational needs; especially the invisible/hidden impairments. 
Data from a focus group discussion with students from a college in Eastern Uganda reveled that "There are very few tutors trained in special needs education deployed at colleges to help in assessing disabilities. There are no tutors who know sign language to manage students with disabilities (Deaf students) in practical subjects that involve use of experiments implementation. This obstructs their abilities to carry out effective continuous assessment of such students" (FGD VI).

Another college reported that "All tutors lacked skills to communicate using Ugandan Sign Language and Braille. This affects their abilities to effectively support student teachers with deafness and blindness" (Tutor II).

A tutor observed "I need training in specialized skills of braille and sign language to help students. I also need skills on how to assess their needs. What we acquire in the college is too general that cannot help me serve students with disabilities. Government should send us tutors with special needs training who knows what to do" (Tutor IV).

The findings provide what actions are being taken by the colleges in relation to enrolment and retention of students with disabilities. It also informs about functional assessment, curriculum and environmental adaptations, use of alternative communications and professional training gaps. The next part interpretes results linking it to the literature. Conclusion and recommendation are made for future research and practice in teacher education.

\section{Discussion}

Many of the study findings are consistent with the challenges special needs and inclusive education experience including "shortage of well-prepared teachers" (Sharma \& Pace, 2019). The many factors that influence training, support and promoting of learning and participation of students in colleges related to lack of functional assessment, attitude towards disability and lack of knowledge in alternative communication skills. Others are lack of knowledge on how to adapt curriculum materials and modify college environment.

There was, however remarkable increase in the number of students with disabilities and other special needs being trained as teachers. Students admitted were being recognized and assigned leadership roles. While this is so, many colleges were admitting students with mild impairments and turning off those with visible and severe disabilities. Physical disability was considered a mild impairment and many of them admitted to train as teachers. Denial of admission to students with disabilities is a denial of one of the fundamental human right (Eron \& Emong, 2017). Failure to admit students with known disabilities denotes the level of understanding of what disability is. The enrolment of some categories of students with special needs and leaving out others is consistent with the findings from Arbeiter and Hartley (2002) on the prevalent social negative attitudes and Kwesiga and Ahikire (2006) on prejudice that led to termination of students with disabilities and Emong \& Eron (2016) on failure to admit students on courses of their choices. These practices influenced the inclu- 
sion and exclusion of some categories of persons with disabilities in education, employment and other social services. It outlaws discrimination in education at all levels. Gabre (2000) and Gabre et al. (2002) advocates for living in less restrictive environments as a means to facilitate inclusive communities where persons with disabilities feel similar to their peers.

A remarkable achievement is reported on classroom organization that takes into consideration students with disabilities and other special educational needs. This finding could be a representation of the response to the professional education requirement and Uganda's policy provisions that emphasize accessibility standards (GoU, 2006). It may demonstrate the vigilance by the Disabled People's Organizations (DPOs) and technical staff in the ministries responsible for school constructions to ensure that there are good walkways, good sitting arrangements, and comfortable writing spaces for students with different abilities.

The shift towards inclusive education argues for improved pedagogy and response to learner diversity (Eron \& Emong, 2017). The professional training gaps resonate well with findings of Khan, Hashmi \& Khanum (2017) on the limited capacity of tutors in the colleges and the lack of specialized skills for tutors who are in the colleges. There is a risk of having inadequately prepared and an unacceptable condition, taking into consideration that teacher quality is the single most important school variable influencing student achievement (Sharma \& Pace, 2019). It may signify why colleges were making and displaying very important and relevant messages without modifying them to reasonably accommodate all students. The lack of reasonable accommodation is consistent with observation by Nyende (2012) on the missing link in corresponding commitment by the government to increase financial support to the university to fulfil its objective. The need and effectiveness of in-service training as a means for quality demonstration of skills should be seen from the way financial support is provided. It calls for the relevance of partnerships in providing resources for the much-needed skills. Collaborating with other agencies forms an integral part of supporting children with special educational needs (SEN) and their parents (Wall, 2008).

It is universally recognized that the main intention of any education system is providing quality education for all. This means all modifications and accommodations are made for learners with disabilities and other special needs in line with the policy. Emong and Eron (2016) advance for policy directives that should require institutions to adopt reasonable accommodation and other equality of opportunities measures for students with disabilities. Other aspects include competent tutors that seriously focus on identification procedures necessary to bring out learners may have more than one problem (Tungaraza, 2014) and components needed to successfully address inclusive education in teacher preparation courses (Symeonidou, 2017).

It is not enough to advocate for inclusive teacher education without taking into consideration the professional and training gaps identified. The intent of pre-service teacher education is to provide the necessary knowledge, competen- 
cies, values and attitudes for an inclusive learning environments (UNESCO, 2013a; Symeonidou, 2017). Teacher educators are responsible to empower, motivate, and professionally prepare the workforce for this mission (Sharma \& Pace, 2019). The professional gaps are consistent to earlier studies on special needs teacher education (Nyende, 2012, Tungaraza, 2014, CSBAG, 2013) on quality teacher and financing of special needs education. A well-structured teacher development and financing of special needs education programmes are very important for successful adjustment and inclusion of students with disabilities and other special needs.

\section{Conclusion and Recommendation}

The analysis was developed based on the changing trends and strategies towards inclusion and inclusive education. It recognizes the significant role teacher education plays in equipping teacher trainees with knowledge, skills and attitudes to promote inclusive education. The proactive observation is that most colleges consider in principle the inclusion of disabilities and special needs as a natural part of their setup. The argument is that special needs education is an integral part of each college planning, budgeting and activities. These considerations are mainly for mild and specific impairments.

The findings from the study have clearly indicated that special needs and inclusive education policies and practices are gaining ground in Uganda. The policies towards inclusion, though appreciated by many partners and institutions, are still more theoretical than practical. The institutions and development partners have the will however, the political, economic, social and technological conditions make it difficult for special needs education to be adopted in colleges. While collaboration between colleges and development partners is on a case by case basis, they are meant to ensure contributions towards inclusive education. It calls for the need for strong collaborations between government, its agencies and development partners.

A number of challenges and strategies for improvement have been identified. The challenges include lack of and/or the failure to admit students with severe disabilities, carry out functional assessment, adaptation of curriculum materials, development of alternative communication skills and modification of college environment. Key points of concern are that issues about education of students with disabilities and other special educational needs are rarely talked about in most colleges. It was also evident that Special Needs Education was a course hidden under Professional Educational Studies and therefore given little attention while tutors in-charge of special needs education were not empowered to handle implementation of special needs and inclusive education activities and programs in the colleges. There was little attention paid to the needs of students with disabilities and other special educational needs enrolled in some colleges and majority of colleges did not have tutors trained in special needs and inclusive education. The increase in the number of students with disabilities and other special needs was recognised. Special skills needing emphasis be identified 
and awareness raised by college teams to ensure effective disability care is increased.

Key recommendations include development of college based institutional policy to provide for reasonable accommodation to ensuring inclusive education. There is need for more sensitization among education planners, implementers and partners to emphasize the needs of students with disabilities. College staff and students should be mentored to realize disability inclusion and inclusive education. Colleges should emphasize functional assessment, curriculum and environmental modification as a means of mainstreaming inclusive learning. The education system should strengthen the knowledge, skills and commitment of teacher educators to provide inclusive practice in their teaching and guidance. Affirmative action in recruitment of students with disabilities to train as role model teachers should be promoted.

\section{Acknowledgements}

The research was funded by Sight Savers Uganda Country Office as a baseline study for the project "Promoting inclusive education through teacher development in Uganda". Permission was sought to publish this information. The author declares that he owns any errors by omission or commission that is identified in this paper.

\section{Conflicts of Interest}

The author declares no conflicts of interest regarding the publication of this paper.

\section{References}

Aguti, J. N. (2003). A Study of In-Service Distance Education for Secondary School Teachers in Uganda: Developing Framework for Teacher Education Programme. Pretoria: University of Pretoria South Africa.

Ahmadi, S., \& Keshavarzi, A. (2013). A Survey of In-Service Training Programs Effectiveness in Teaching Skills Development from the View-Point of Students, Teachers and Principals of Guidance Schools in Shiraz. Procedia-Social and Behavioral Sciences, 83, 920-925. https://doi.org/10.1016/j.sbspro.2013.06.172

Arbeiter, S., \& Hartley, S. (2002). Teachers' and Pupils' Experiences of Integrated Education in Uganda. International Journal of Disability, Development and Education, 49, 61-78. https://doi.org/10.1080/10349120120115334

Booth, T. (2009). Keeping the Future Alive: Maintaining Inclusive Values in Education and Society. In M. Alur, \& V Timmons (Eds.), Inclusive Education across Cultures (pp. 121-134). Sage. https://doi.org/10.4135/9788132108320.n9

Buysse, V., \& Peisner-Feinberg, E. (2010). Recognition \& Response: RTI for Pre-K. Young Exceptional Children, 13, 2-13. https://doi.org/10.1177/1096250610373586

Cilliersa, J., Kasirye, I., Leaver, C., Serneels, P., \& Zeitline, A. (2014). Improving Teacher Attendance Using a Locally Managed Monitoring Scheme: Evidence from Ugandan Primary Schools. Policy Note 14/0189, International Growth Centre. https://www.theigc.org/wp-content/uploads/2014/09/Cilliers-Et-Al-2014-Policy-Brief.p 
CSBAG (2013). Financing Special Needs Education in Uganda: Tracking Flow of Funds for Special Needs in Abim, Kibale and Agago Districts. Kampala: Civil Society Budget Advocacy Group/Democratic Governance Facility.

Daumerie, B., \& Madsen, E. L. (2010). The Effects of a Very Young Age Structure in Uganda: Country Case Study. Population Action International.

Denzin, N. K., \& Lincoln, Y. S. (2000). Introduction: The Discipline and Practice of Qualitative Research. In N. K. Denzin, \& Y. S. Lincoln (Eds.), Handbook of Qualitative Research (2nd ed., pp. 1-32). Sage.

Emong, P., \& Eron, L. (2016). Disability Inclusion in Higher Education in Uganda: Status and Strategies. African Journal of Disability, 5, a193.

https://doi.org/10.4102/ajod.v5i1.193

Eron, L., \&Emong, P. (2017). Tackling Education of Girl Child with Disability in Urban Setting of Uganda. In W. T. Pink, \& G. W Noblit (Eds.), Second International Handbook on Urban Education (pp. 51-65). Springer International of Education. ttps://doi.org/10.1007/978-3-319-40317-5 5

Gabre, P. (2000). Studies in Oral Health in Mentally Retarded Adults. Swedish Dental Journal Supplement, 13, 142-148.

Gabre, P., Martinsson, T., \& Gahnberg, L. (2002). Move of Adults with ID from Institutions to Community-Based Living: Changes of Food Arrangements and Oral Health. Swedish Dental Journal, 26, 81-88.

GoU (2006). The Persons with Disabilities Act. Kampala: UPPC.

https://www.ilo.org/wcmsp5/groups/public/---ed protect/---protrav/---ilo aids/docum ents/legaldocument/wcms 232181.pdf

Khan, I. K., Hashmi, S. H., \& Khanum, N. (2017). Article Inclusive Education in Government Primary Schools: Teacher Perceptions. Journal of Education and Educational Development, 4, 32-47. https://doi.org/10.22555/joeed.v4i1.1331

Kwesiga, J. C., \& Ahikire, J. (2006). On Student Access and Equity in Reforming University: Makerere in the 1990s and beyond. JHEA/RESA. https://codesria.org/IMG/pdf/1-Kwesiga-Ahikireb.pdf

Mann, S. (2005). The Language Teacher's Development. Language Teaching, 38, 103-118. https://www2.warwick.ac.uk/fac/soc/al/people/mann/mann s/stateof.pdf https://doi.org/10.1017/S0261444805002867

Mather, G., \& Muchatuta, M. (2011). How to Teach with Inclusive Practice. Learning through Diversity. Sydney: Macquarie University.

Moyi, P. (2012). Access to Education for Children with Disabilities in Uganda: Implications for Education for All. Journal of International Education and Leadership, 2, 1-13. https://files.eric.ed.gov/fulltext/EJ1136042.pdf

Najingo, H. (2009). Challenges of Accessing All-Inclusive Education Services by Children with Disabilities (CWDs): A Case Study of Mijwala Sub-County, Sembabule District. Unpublished Masters Theses, Kampala: Makerere University. http://makir.mak.ac.ug/handle/10570/2461

Nyende, F. (2012). Children with Disabilities in Universal Primary Education in Uganda: A Rights-Based Analysis to Inclusive Education. Human Rights, Development and Social Justice (HDS). http://hdl.handle.net/2105/13189

Patton, M. Q. (2002). Qualitative Research and Evaluation Methods (3rd ed.). Sage.

Sharma, U., \& Pace, E. M. (2019). Teachers' Commitment to Teach in Inclusive Schools, Preparation of. In M. A. Peters (Ed.), Encyclopedia of Teacher Education. Springer. 
https://doi.org/10.1007/978-981-13-1179-6 41-1

Silverman, D. (2010). Doing Qualitative Research (3rd ed.). Sage.

Stockall, N. S., Dennis, L., \& Miller, M. (2012). Right from the Start: Universal Design for Preschool. TEACHING Exceptional Children, 45, 10-17. https://doi.org/10.1177/004005991204500103

Sulochini, P., \& Slee, R. (2019). Exploring Inclusive Education and "Inclusion" in the African Context. In P. Sulochini, \& R. Slee (Eds.), Challenging Inclusive Education Policy and Practice in Africa (pp. 1-14). Brill Sense.

Symeonidou, S. (2017). Initial Teacher Education for Inclusion: A Review of the Literature. Disability \& Society, 32, 401-422. https://doi.org/10.1080/09687599.2017.1298992

Tschantz, J. M., \& Vail, C. O. (2000). Effects of Peer Coaching on the Rate of Responsive Teacher Statements during a Child-Directed Period in an Inclusive Preschool Setting. Teacher Education and Special Education, 23, 189-201. https://doi.org/10.1177/088840640002300302

Tumwebaze, C., \& MacLachlan, M. (2012). Motivating the Teacher Workforce in Uganda. In S. C. Carr, M. MacLachlan, \& A. Furnham (Eds.), Humanitarian Work Psychology (pp. 166-181). London: Palgrave Macmillan. https://doi.org/10.1057/9781137015228 7

Tungaraza, F. D. (2014). Training Teachers in Special Needs Education in Tanzania: A Long and Challenging Ordeal to Inclusion. Huria: Journal of the Open University of Tanzania, 16, 49-60. https://www.ajol.info/index.php/huria/article/view/108739

UN (2015). Transforming Our World: The 2030 Agenda for Sustainable Development. A/RES/70/1, UN.

https://www.un.org/ga/search/view doc.asp?symbol=A/RES/70/1\&Lang=E

UNESCO (2013a). Promoting Inclusive Teacher Education Introduction. UNESCO.

UNESCO (2013b). Teacher Issues in Uganda: A Shared Vision for an Effective Teachers Policy. Kampala: Ministry of Education and Sports.

http://www.teachersforefa.unesco.org/v2/phocadownload/Country Support/tissa ugan da full report.pdf

Wall, K. (2008). Special Needs and Early Years (2nd ed.). SAGE. 